\title{
Unethical studies on transplantation in cardiothoracic surgery journals
}

\author{
Robert M. Sade, MD, ${ }^{\mathrm{a}}$ Andrea J. Carpenter, MD, ${ }^{\mathrm{b}}$ Thomas A. D'Amico, MD, ${ }^{\mathrm{c}}$ Daniel H. Drake, MD, ${ }^{\mathrm{d}}$
} John W. Entwistle III, MD, PhD, ${ }^{\mathrm{e}}$ Shuddhadeb Ray, MD, ${ }^{\mathrm{f}}$ and James $\mathrm{S}$. Tweddell, $\mathrm{MD}^{\mathrm{g}}$

Executed prisoners have been a source of organs for transplantation in several countries; for example, Taiwan, Singapore, and China. ${ }^{1}$ Taiwan and Singapore have long since stopped the practice, but China has not. Taking organs by coercive methods has been documented in some countries, such as India and Egypt, ${ }^{2}$ but unlike China, this practice is illegal and subject to criminal prosecution in those jurisdictions.

Over the last 20 years, increasing attention has been paid to a troubling feature of transplantation in the People's Republic of China (PRC): harvesting of a large number of organs from nonconsenting prisoners, mostly prisoners of conscience (based on race/ethnicity, sexual orientation, religion, or political views). Some observers have called for journals to reject all such papers on grounds that taking organs without consent is a severe violation of biomedical ethics and that studies resulting from them are unethical. ${ }^{3,4}$ The lack of transparency of transplant organ sources in the PRC has led to uncertainty about the severity of the problem, so only a few journals have acted on the recommendation to reject transplant papers from the PRC. ${ }^{5}$

The reality and extent of forced organ harvesting was described in 2020 by the final report of The China Tribunal, a nongovernmental inquiry into forced organ harvesting in China, which documented that prisoners in the PRC have been executed for their organs for decades and that the practice still continues. ${ }^{6}$ In light of this new information, journals should consider how to handle clinical transplant articles from programs that engage in severe violation of ethical norms.

\footnotetext{
From the ${ }^{\mathrm{a}}$ Department of Surgery, Institute of Human Values in Health Care, Medical University of South Carolina, Charleston, SC; ${ }^{b}$ Division of Thoracic Surgery, University of Texas Health Science Center, San Antonio, Tex; ${ }^{\mathrm{c} D e p a r t m e n t ~ o f ~ S u r g e r y, ~}$ Duke University Medical Center, Durham, NC; ${ }^{\mathrm{d}}$ Department of Surgery, Munson Healthcare, Traverse City, Mich; ${ }^{\mathrm{e}}$ Division of Cardiothoracic Surgery, Thomas Jefferson University, Philadelphia, Pa; ${ }^{\mathrm{f}}$ Department of Surgery, Washington University in St. Louis School of Medicine, St Louis, Mo; and ${ }^{\mathrm{g}}$ Department of Surgery, Cincinnati Children's Hospital Medical Center, Heart Institute, Cincinnati, Ohio.

This article has been copublished in The Journal of Thoracic and Cardiovascular Surgery and The Annals of Thoracic Surgery.

Received for publication April 22, 2021; revisions received July 25, 2021; accepted for publication July 25, 2021; available ahead of print Oct 12, 2021.

Address for reprints: Robert M. Sade, MD, Department of Surgery, Institute of Human Values in Health Care, Medical University of South Carolina, 30 Courtenay Dr, MSC 295, Charleston, SC 29425-2950 (E-mail: sader@musc.edu).

J Thorac Cardiovasc Surg 2021;162:1647-53 $0022-5223 / \$ 36.00$

Copyright (c) 2021 Jointly between The Society of Thoracic Surgeons and The American Association for Thoracic Surgery. Published by Elsevier Inc.

https://doi.org/10.1016/j.jtcvs.2021.07.061
}

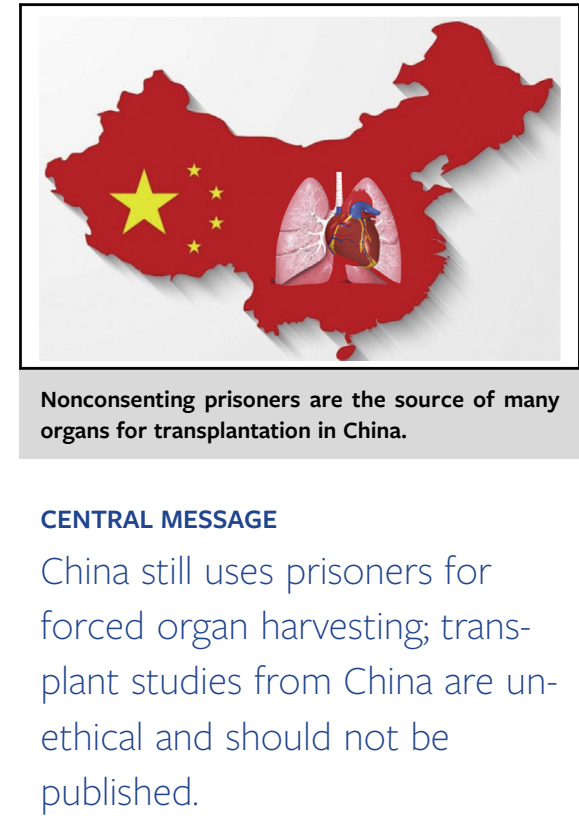

ORGAN SOURCING AND TRANSPLANTATION IN THE PRC

Transplantation began in the PRC with the first kidney transplant in 1959 but remained uncommon until the 1980 s, when an increase in transplants was motivated by the introduction of cyclosporine..$^{7}$ The limited availability of volunteers for living or deceased donation resulted in a small number of transplants for many years. The severe shortage of organ donors was related to cultural factors principally based on the pervasive influence of Confucianism on both public opinion and official government policy. ${ }^{1}$ One is born with a complete body - a gift from one's parents-and life should end with the body intact. ${ }^{8}$ As a result, from 1977 to 2009, a mere 130 deceased individuals donated organs, according to Huang Jiefu, China's Vice Minister of Health and architect of the China Organ Transplant Response System. ${ }^{9}$ Yet during that same period, 120,000 transplants were performed, ${ }^{10}$ and according to Huang, most of those organs came from prisoners. ${ }^{9}$

The first known cases of organ harvesting from prisoners of conscience were Muslim activists from the disfavored Uyghur population in $1997 .^{11}$ Most of those executed have been prisoners of conscience, especially members of 
the Falun Gong, a nonviolent and peaceable spiritual movement that is based in Buddhism, founded in the early 1990s. The PRC government and the Chinese Communist Party viewed it as a threat because of its growing popularity. ${ }^{12}$ Persecution of the Falun Gong began in 1999, including torture. Execution to obtain organs for transplantation on demand began in $2001,{ }^{13}$ which is when organ harvesting rapidly accelerated. This source of organs remained an official secret until 2005, although Chinese authorities continued thereafter to vehemently deny using prisoners for transplant organs without their consent. In 2013 Huang admitted that organs had been taken from nonconsenting prisoners for decades. ${ }^{14}$

In response to an international outcry about the use of involuntary prisoner organs, a regulation in 1984 required that organs could not be taken without explicit consent of the donor or the donor's family. ${ }^{15}$ This was largely ignored, however, resulting in the PRC promulgating a second set of regulations in 2007, again requiring consent for organ donation and committing to end the use of prisoners as a source of organs. ${ }^{15}$

Huang announced in 2014 that only voluntarily donated organs would be used for transplantation after January 1, 2015, the donation system would be transparent, and the origin of all organs would be traceable. ${ }^{15}$ The use of organs from executed prisoners was not prohibited, however; they would presumably voluntarily donate their organs. Robertson and colleagues ${ }^{16}$ found evidence that several transplant surgeons misclassified donors as voluntary when in fact they were not. The reforms of 2015 were not supported by laws or regulations; they were only advisory and have been largely ignored. ${ }^{10}$

Chinese officials claim that organs are not harvested from donors until they are determined to be brain dead, yet as of 2020 the PRC has no brain death legislation. ${ }^{6}$ At least 38 cases have been documented in which endotracheal intubation was performed after brain death was declared; the patients were spontaneously breathing at the time death was declared, clearly alive by any acceptable international standard. ${ }^{11}$

Given this history, particularly that of a vast difference between the relatively small number of officially reported transplants and the calculated large number of actual transplants, Robertson and colleagues ${ }^{16}$ investigated that discrepancy by examining available data sets regarding PRC's voluntary donation system from 3 independent official sources. Using sophisticated statistical analytic techniques, they determined that the many "unusual and anomalous features of the data are due to deliberate human intervention." They also concluded that "this intervention could not have been piecemeal or without forethought," and that "the only plausible explanation that accounts for all of our observations is that the three datasets were manufactured and manipulated from the central levels of the Chinese medical bureaucracy."

Since the reforms of 2015, efforts to increase voluntary donation are taking place in China, yet most of the organ pool still comes from nonvoluntary donors, misclassified as voluntary citizen donors. ${ }^{16}$ One of the most unfortunate consequences of the ongoing use of executed prisoner organs is the damage to the international reputations and standings of those transplant surgeons in China who are dedicated to high ethical standards in their practices and are making vigorous and honest efforts to establish a transparent and trustworthy system. ${ }^{16}$

\section{THE CHINA TRIBUNAL}

The most devastating blow to China's pretentions of adherence to international ethical standards in transplantation was delivered in 2020 by The China Tribunal, an independent and diverse group of investigators who studied organ transplantation in the PRC. ${ }^{17}$ The Tribunal is chaired by Sir Geoffrey Nice, a British barrister known for his work as a prosecutor of international criminal activity. Other members include British cardiothoracic surgeon Martin Elliott and noted American historian of China Arthur Waldron. $^{18}$ Details of its charter, membership, methods, jurisdiction, and authority to act can be found in its recent publication. ${ }^{17}$

The Tribunal found and evaluated both direct and indirect evidence of the use of involuntary prisoners as a source of organs for transplantation in China, including investigative books and articles, reports of formal inquiries by national and international bodies, and the testimony of witnesses at hearings that were open to the public and are publicly available as video recordings. ${ }^{19}$

The Tribunal released its 562-page final judgment on March 1, 2020. ${ }^{5}$ Starting with a presumption of innocence, it collected a wide range of direct and indirect evidence of forced organ harvesting-defined as "killing a person without their consent in order that their organs may be removed and transplanted into another person"-and several other specific crimes. It also evaluated evidence and arguments favorable to the PRC from numerous public and private sources. For purposes of this report, we focus only on The Tribunal's evidence and findings related to forced organ harvesting, omitting discussion of the several other crimes it identified.

As the PRC remains closed to any independent investigation of organ transplantation, The Tribunal was impeded in gathering information about the extent of executed prisoners being used as a source for transplantable organs. Despite this limitation, it investigated PRC transplant practices through study of available documents and through direct written and oral testimony, and it meticulously reported its sources of information, its findings, and its final conclusions. 
Among its findings were these:

- "Very large numbers of transplant operations have been carried out in the PRC. The Tribunal assesses as credible numbers of operations between 60,000 and 90,000 per annum in the years 2000-2014. This, when compared to the number of eligible registered donors, which, by 2017, had risen to 5,146, leaves an incomprehensible gap. To achieve the numbers of transplants performed-before and since 2017, the year of most recent estimate-there must have existed another source or other sources of tissue-typed organs; this in turn shows that there must have existed a group of donors unidentified in PRC material.” (P 150, \455)

- The Tribunal reached a "certain conclusion" that "Hospitals in the PRC have had access to a population of donors whose organs could be extracted according to demand for them." (P 150, ๆ456)

- "Forced organ harvesting has happened in multiple places in the PRC and on multiple occasions for a period of at least 20 years and continues to this day." (P 150, ฯ457)

- "In the long-term practice in the PRC of forced organ harvesting it was indeed Falun Gong practitioners who were used as a source — probably the principal source—of organs for forced organ harvesting." (P 151, \461)

- "Coincident with the developing persecution of practitioners of Falun Gong over time has been an enormous, unexplained provision of transplant infrastructure, in the absence of a voluntary organ donor system." (P 151, ๆ 463)

- About the question of whether forced organ harvesting has ended, The Tribunal concluded: "[T]he system has been in operation for years despite international evidence-based concerns and criticism, and research asserting that the practice is proved. There is, thus, no particular reason for it to stop and many people's livelihoods in the PRC depend on it.... Further still, it would appear probable that access to a supply of organs has been one of the reasons the PRC has been able to become so formidable in the skills required for transplant surgery and thus to rise-subject to the shadow of these allegations-in the estimation of transplant surgeons elsewhere in the world... There is no evidence of the practice having been stopped and the Tribunal is satisfied that it is continuing." (P 152, ๆ467).

\section{EVIDENCE IN SUPPORT OF THE PRC}

The Tribunal also evaluated the available evidence that was favorable to the PRC. ${ }^{17} \mathrm{~A}$ few transplant doctors have spoken positively of the organ donation reforms, but none has offered any evidence (eg, reviews of hospital or prison records or interviews of patients or organ donors) in support of their views. The Transplant Society and the
World Health Organization have spoken positively of the 2015 reforms in organ donation and appear to simply accept the PRC's organ source data at face value, data that Robertson and colleagues ${ }^{14}$ have shown to be unreliable. No government has condemned the criminality of the PRC's transplant system, and the Tribunal's detailed review indicated that no government body has sought a thorough analysis of evidence related to the widespread allegations of forced organ harvesting since $2001 .^{17}$ The PRC itself has either not reacted to the allegations, or, when it has reacted, has simply denied wrongdoing and claimed that accusers were lying. It has never produced evidence contradicting the demonstration of its manipulation and falsification of organ source data by Robertson and colleagues. ${ }^{14}$

\section{ETHICS OF PUBLICATION IN SCIENTIFIC JOURNALS}

The subjects of the first known scientific research performed on human beings were 6 prisoners in Newgate prison in 1721. They were scheduled to be hanged, but they "volunteered" to undergo smallpox vaccination when offered the grant of a pardon by King George I. ${ }^{20}$ Prisoners were used in many subsequent studies ${ }^{21}$ including the most notorious series of horrendous experiments on prisoners, those by Nazi physicians during World War II. ${ }^{22}$

Some have argued that prisoners should not be allowed to donate at all on several grounds, including that the prison environment is inherently coercive. ${ }^{23}$ This view has been countered with the argument that, at least theoretically, administrative safeguards could prevent coercion. The weight of the ethics literature supports not using prisoners at all. There is no question, however, that an absolute requirement of organ donation is that it be voluntary. Every international statement on organ donation supports that view, including the World Health Organization ${ }^{24}$ and the World Medical Association. ${ }^{25}$

A long history of unethical experiments on human beings has been documented - on prisoners, institutionalized children, armed forces personnel, and others-and they lead to a central question related to the publication of data from such studies: Should research that involved a violation of biomedical ethics be published at all ${ }^{26}$ That essentially ethical question has been addressed in several different ways that Higgins and colleagues ${ }^{27}$ have explicated in detail.

Consequentialist arguments weigh the benefits (eg, the potential value of the research results) and the harms (eg, validation of the unethical methods used, and encouraging or failing to discourage unethical research). Given the evidence cited above, the harms of publication of Chinese transplant research using unethically sourced organs weigh more heavily than the benefits. ${ }^{27}$

Deontological arguments can be adduced in favor or against publication of unethical research. Supporting 
publication is the view that all knowledge is inherently valuable, leading to the need for open sharing of all research data. An opposing view holds that egregious violations of research ethics should disqualify dissemination of information. ${ }^{27}$ According to The Tribunal, the egregious ethical and legal violation of forced organ recovery constituting crimes against humanity has been occurring in the PRC for decades and continues still, beyond a reasonable doubt. Attempts to benefit from such severe ethical violations through publication can undermine protests against those violations. Moreover, publishers and users of unethically obtained data become morally tainted and, as some have argued, complicit in the wrongdoing. ${ }^{28}$

Most of the literature related to the ethics of publishing unethical research focuses on historical examples, such as the 1940s Holocaust experiments by German doctors and others. The case of Chinese transplantation is as ethically intolerable as those examples. To make matters worse those ethical violations are not merely historical-they are ongoing, and without substantial consequences to the use of organs from executed prisoners, those procuring such organs have little incentive to stop.

\section{HOW SHOULD PUBLICATIONS RESPOND TO CHINA'S USE OF PRISONERS AS ORGAN DONORS?}

Journal editors have many responsibilities in choosing to publish or to reject scientific information, as do others, such as conference program committees. Prominent among them is the responsibility to maintain the integrity of science, including the protection of human subjects and enforcement of ethical norms. Journals require authors to disclose certain facts related to these responsibilities in their manuscript submission instructions. Editors have no way to ensure that ethical norms have in fact been observed by authors or by those who supply information and research materials to the authors, so in the interest of collegiality and trust in authors' adherence to the norms of science, editors necessarily accept the reported conditions of research at face value. Trust is not completely blind, however, and journals occasionally identify transgressions of proper scientific conduct - such as fabrication or falsification of data-and deal with them accordingly. Trust in the ethical foundation of an investigation in transplantation cannot exist when external objective validation of the data is prohibited.

Ethics-related policies of most journals require ethical conduct of research and refer to general international prohibitions of unethical research, such as the Declaration of Helsinki ${ }^{29}$ and the International Committee of Medical Journal Editors statement on Protection of Research Participants. ${ }^{30}$ Some international organizations have made specific statements about the sourcing of organs from executed prisoners.
- World Health Organization: "Physicians and other health professionals should not engage in transplantation procedures... if the cells, tissues or organs concerned have been obtained through exploitation or coercion of, or payment to, the donor or the next of kin of a deceased donor. The organization and execution of donation and transplantation activities, as well as their clinical results, must be transparent and open to scrutiny." 31

- World Medical Association: "In jurisdictions where the death penalty is practised, executed prisoners must not be considered as organ and/or tissue donors." 25

- International Society of Heart and Lung Transplantation: "Obtaining organs for transplantation from the bodies of executed prisoners contravenes the principle of voluntary donation. A condemned prisoner and his relatives cannot consent freely." 32

- The Transplantation Society: "The Transplantation Society is opposed to the recovery of organs from executed prisoners. It is a fundamental principle for The Transplantation Society that organs and tissues are given freely and without coercion. Because of the restrictions in liberty in a prison environment, it is unlikely that prisoners are truly free to make independent decisions and thus an autonomous informed consent for donation cannot be obtained." ${ }^{33}$

A few transplantation journals have made specific statements on the use of prisoners as a source of organs.

- Transplantation: "Transplantation and our sister journal, Transplantation Direct, will not knowingly publish any material that has been derived in any part from the use of organs from executed people." ${ }^{34}$

- American Journal of Transplantation: "AJT does not accept manuscripts whose data derives from transplants involving organs obtained from executed prisoners."

- The Journal of Heart and Lung Transplantation requires a "Statement of compliance with the ISHLT Ethics statement." ${ }^{35}$ (We have cited the ISHLT statement above. ${ }^{32}$ )

We have focused on China as the subject of this document because it is the only country that is known to sponsor the use of involuntary organ donors as sources of organs for transplantation. The International Society for Human Rights has found that forceful taking of organs occurs elsewhere in the world, such as in India and Egypt, ${ }^{2}$ where it is illegal and subject to criminal sanctions. No government accepts this practice, except for China, in which forced organ harvesting is supported by the state.

It is no longer reasonable to take at face value assurances from official sources in the PRC that only voluntary donors are the source of transplant organs. Official denials of use of nonvoluntary prisoners are not credible. Chinese transplantation information can be accepted as based on ethically performed transplant operations when Chinese authorities 
allow objective third-party independent investigations of the origins of donated organs. It is possible that some of the major transplant hospitals use organs only from voluntary donors, but the origins of transplanted organs cannot be accepted on the basis of a statement in a submitted paper because widespread falsification of organ source data within the PRC has been documented. ${ }^{16}$ Transparent and credible documentation of organ sources should be required before a paper can be accepted. Although we have found no evidence of state-sanctioned forced organ harvesting in any other country, it is possible that subjects of papers submitted from transplant centers elsewhere in the world may include nonconsented donors. When forced organ harvesting is suspected, documentation of organ sources should be required.

Scientific journals must necessarily trust in the honesty of all aspects of the reports they publish, and after the PRC government's promise in 2015 that all transplant organs would come from volunteer donors, international journals have largely accepted the ethical legitimacy of transplant papers from China. Despite the hope for real change, ${ }^{36}$ that promise has not been realized. As Robertson and colleagues stated, "The welcoming of China's organ transplantation system into the international medical community has been based on trust; in light of our findings, we believe this trust has been violated." 16

The evidence has become overwhelming. There can be no reasonable doubt that prisoners are being executed for their organs in the PRC. Journals can no longer blindly trust in the purported ethical sourcing of organs in transplant papers from the PRC and should treat transplant studies from the PRC as severely flawed owing to the documented egregious ethical violation of forced organ harvesting.

At least four approaches are available for journals to respond to transplant papers that are ethically flawed. The first has been used in the past: ethical violations identified in a paper usually result in rejection, but if the paper's data are very important and cannot be replicated, the paper may be published along with a statement identifying the transgression, condemning it, and explaining the justification for its publication. ${ }^{26}$

A second approach has been used by a few journals, specifically applied to Chinese transplant papers, which would be considered for publication only if the authors attested that consent for donation was obtained from the donor or the donor's family and that no organs were obtained from executed prisoners. ${ }^{37,38}$

A third approach may apply when the ethics violation is so extreme that a ban on such publications is justified. ${ }^{3}$

A fourth approach has been used by the journal Transplantation, which requires all authors of transplant papers to describe the origin of transplanted organs and affirm that ethical boundaries are observed and research approvals are transparent. ${ }^{35}$ The journal has applied this standard to current submissions as well as to papers already published: 7 previously published papers were retracted when the authors did not respond to queries or could not validate the source of their organs. ${ }^{35}$

Papers presented at cardiothoracic surgery annual meetings must be submitted to the meetings' respective journals for consideration for publication, so meeting organizers should ensure that all presented data meet ethical and legal transplantation standards.

Beyond submissions, several hundred papers currently published in the transplant literature certainly used data from executed prisoners of conscience before 2010, the year a pilot program of volunteer donors began, and probably used such data thereafter, including the period after the 2015 unfulfilled promise of transition to volunteer donation. Rogers and colleagues ${ }^{5}$ have made a cogent case for retraction of all Chinese transplant papers from the scientific literature on grounds that allowing published research to remain in the literature shows "lack of respect and concern for the victims and undermines efforts to deter unethical practices." Several journals have retracted Chinese transplant papers on grounds of the use of organs from executed prisoners, including Transplantation's retraction of 7 such papers $^{39}$ and PLoS One, which has retracted 21 papers. ${ }^{40}$

\section{RECOMMENDATION}

Although China is the only country that currently allows the use of prisoners as a source of organs for transplantation, ${ }^{33}$ all transplant papers submitted to a journal should be subject to the same ethical requirements, namely, documentation of prospective approval of research protocols by an ethics review board, clear informed consent procedures, transparency of the sources of donor organs, and freedom of donors from any form of coercion. Failure of authors to provide adequate information or to respond to editors' requests to provide the information should result in rejection of the paper.

Because of China's documented use of organs from nonconsenting prisoners in the past, authors of Chinese transplant papers already published should be required to supply information about patients and donors in their studies, the sources of donated organs, and any form of coercion in procuring organs, including prisoners. Failure to supply transparent information or to respond to requests for information should result in retraction of the paper.

Organizers of scientific meetings should be aware of ethical and legal standards related to transplantation and should anticipate journal requirements in their requests for submission of abstracts.

We make these recommendations because of the need to maintain the ethical integrity of our scientific foundations and publications, to respect the victims of forced organ harvesting, and to avoid any taint of editorial complicity in the 
continuing execution of nonconsenting prisoners for their organs. If any surgeon-scientists are prevented from presenting or publishing their studies because they cannot or will not provide the required documentation of informed consent or of voluntary organ donation, we hope that they, their organizations, or their country will be motivated to join the international transplant community's commitment to and practice of ethical organ procurement and transplantation.

\section{Conflict of Interest Statement}

The authors reported no conflicts of interest.

The Journal policy requires editors and reviewers to disclose conflicts of interest and to decline handling or reviewing manuscripts for which they may have a conflict of interest. The editors and reviewers of this article have no conflicts of interest.

The authors wish to recognize for their collaboration and discussion in the authors' preparation of this report: Leah Backhus, MD, David Blitzer, MD, DuyKhanh P. Ceppa, MD, Robbin G. Cohen, MD, Joseph A. Dearani, MD, Kathleen N. Fenton, MD, Matthias Loebe, MD, Martin F. McKneally, MD, Walter H. Merrill, MD, J. Scott Millikan, MD, Susan D. Moffatt-Bruce, MD, Sudish C. Murthy, MD, Mark B. Orringer, MD, Allan Pickens, MD, Jennifer C. Romano, MD, Julie Swain, MD, Richard I. Whyte, MD, and Joseph B. Zwischenberger, MD. Dr Sade's role in this publication was supported by the South Carolina Clinical \& Translational Research Institute, Medical University of South Carolina's Clinical and National Institutes of Health, National Center for Advancing Translational Sciences award number UL1TR001450. The contents are solely the responsibility of the authors and do not necessarily represent the official views of the National Center for Advancing Translational Science of the National Institutes of Health.

\section{References}

1. Ikels C. Ethical issues in organ procurement in Chinese societies. China J. 1997; 38:95-119.

2. International Society for Human Rights. China: Organ Harvesting. Available at: https://ishr.org/organ-harvesting/. Accessed June 17, 2021.

3. Rogers WA, Ballantyne A, Higgins WC, Lipworth W. Clamping down on unethical research: time for a moratorium on publishing Chinese transplant research. Journal of Medical Ethics Blog. July 2, 2020. Available at: https://blogs.bmj. com/medical-ethics/2020/07/02/clamping-down-on-unethical-research-time-fora-moratorium-on-publishing-chinese-transplant-research/. Accessed February 2, 2021.

4. Trey T, Sharif A, Schwarz A, Fiatarone Singh M, Lavee J. Transplant medicine in China: need for transparency and international scrutiny remains. Am J Transplant. 2016;16:3115-20.

5. Rogers W, Robertson MP, Ballantyne A, et al. Compliance with ethical standards in the reporting of donor sources and ethics review in peer-reviewed publications involving organ transplantation in China: a scoping review. BMJ Open. 2019; 9:e024473.

6. The Independent Tribunal into Forced Organ Harvesting from Prisoners of Conscience in China. Judgment; March 1, 2020. Available at: https://chinatribunal. com/wp-content/uploads/2020/03/ChinaTribunal_JUDGMENT_1stMarch_2020. pdf. Accessed January 26, 2021.

7. Xu L, Chen H, Chen J, et al. The consensus on indications, conditioning regimen, and donor selection of allogeneic hematopoietic cell transplantation for hematological diseases in China-recommendations from the Chinese Society of Hematology. J Hematol Oncol. 2018;11:33.
8. Brannigan MC. Organ extraction from executed prisoners: confucian considerations. Am J Bioeth. 2010;10:27-8.

9. Zhao HWN. China's Organ Transplant will step onto the world. CN-Healthcare. Available at: http://med.china.com.cn/content/pid/14244/tid/3. Accessed January 26, 2021.

10. Allison KC, Caplan A, Shapiro ME, Els C, Paul NW, Li H. Historical development and current status of organ procurement from death-row prisoners in China. BMC Med Ethics. 2015;16:85.

11. Kilgour D, Gutmann E, Matas D. Bloody Harvest / The Slaughter-An Update. International Coalition to End Transplant Abuse in China. April 30, 2017. Available at: https://endtransplantabuse.org/wp-content/uploads/2017/05/Bloody_Ha rvest-The_Slaughter-2016-Update-V3-and-Addendum-20170430.pdf. Accessed January 31, 2021.

12. The Politburo's Predicament Confronting the Limitations of Chinese Communist Party Repression. A Freedom House Special Report. January 2015. Freedom House. Available at: https://web.archive.org/web/20160417122423/https://free domhouse.org/sites/default/files/12222014_FH_ChinaReport2014_FINAL.pdf. Accessed January 29, 2021.

13. Trey T, Caplan AL, Lavee J. Transplant ethics under scrutiny-responsibilities of all medical professionals. Croat Med J. 2013;54:71-4.

14. Robertson M. Chinese Medical Official Admits That Organs Were Extracted Without Consent. The Epoch Times; Updated August 27, 2013. Available at: https://www.theepochtimes.com/chinese-medical-official-admits-that-organs-we re-extracted-without-consent_263294.html. Accessed January 29, 2021.

15. Huang J, Wang H, Fan ST, et al. The national program for deceased organ donation in China. Transplantation. 2013;96:5-9.

16. Robertson MP, Hinde RL, Lavee J. Analysis of official deceased organ donation data casts doubt on the credibility of China's organ transplant reform. BMC Med Ethics. 2019;20:79.

17. China Tribunal: Independent Tribunal into Forced Organ Harvesting From Prisoners of Conscience in China. Available at: https://chinatribunal.com. Accessed January 31, 2021.

18. Who we are: the Tribunal panel. China Tribunal. Available at: https:// chinatribunal.com/who-we-are. Accessed January 28, 2021.

19. China Tribunal: The Hearings: December 2018. Available at: https:// chinatribunal.com/the-hearings/. Accessed September 7, 2021.

20. Boylston A. The Newgate Guinea Pigs. London Historians. September 2012. Available at: https://webcache.googleusercontent.com/search?q=cache:097v Au5IAiwJ; https://www.londonhistorians.org/index.php. Accessed February 1, 2021.

21. Hornblum AM. They were cheap and available: prisoners as research subjects in twentieth century America. BMJ. 1997;315:1437-41.

22. Grodin M. Historical origins of the Nuremberg Code. In: Annas GJ, Grodin MA, eds. The Nazi Doctors and the Nuremberg Code: Human Rights in Human Experimentation. Oxford University Press; 1992:121-44.

23. Cameron JS, Hoffenberg R. The ethics of organ transplantation reconsidered: paid organ donation and the use of executed prisoners as donors. Kidney Int. 1999;55:724-32.

24. World Health Organization. WHO guiding principles on human cell, tissue and organ transplantation. Transplantation. 2010;90:229-33.

25. World Medical Association. WMA statement on organ and tissue donation. August 21, 2020. Available at: https://www.wma.net/policies-post/wma-state ment-on-organ-and-tissue-donation/. Accessed June 23, 2021

26. Sade RM. Publication of unethical research studies: the importance of informed consent. Ann Thorac Surg. 2003;75:325-8.

27. Higgins WC, Rogers WA, Ballantyne A, Lipworth W. Against the use and publication of contemporary unethical research: the case of Chinese transplant research. J Med Ethics. 2020;46:678-84.

28. Mellema G. Collective Responsibility. Rodopi Press; 1997 [quoted in Higgins and colleagues $\left.{ }^{27}\right]$.

29. World Medical Association. WMA Declaration of Helsinki-Ethical Principles for Medical Research Involving Human Subjects. July 9, 2018. Available at: https://www.wma.net/policies-post/wma-declaration-of-helsinki-ethical-princip les-for-medical-research-involving-human-subjects/. Accessed June 23, 2021.

30. International Committee of Medical Journal Editors. Protection of Research Participants. Available at: http://www.icmje.org/recommendations/browse/rolesand-responsibilities/protection-of-research-participants.html. Accessed June 23, 2021.

31. Sixty-Third World Health Assembly, World Health Organization. WHO guiding principles on human cell, tissue and organ transplantation. Cell Tissue Bank. 2010;11:413-9. 
32. International Society for Heart and Lung Transplantation Statement on Transplant Ethics. Approved April 2007. Updated October 2014. Available at: https://ishlt.org/ishlt/media/ISHLT/Content\%20Documents/ISHLT_Statement_ on_Transplant_Ethics_19-Oct-2014.pdf. Accessed June 23, 2021.

33. The Transplantation Society. Governance: Policy and Ethics. Available at: https://tts.org/tts-about/tts-governance. Accessed June 23, 2021.

34. Chapman JR, Stock P, Haberal M. Organs from executed people are not a source of scientific discovery. Transplantation. 2019;103:1534-5.

35. Journal of Heart and Lung Transplantation. Guide for Authors: JHLT Operating Procedures, Policies and Information for Authors. Available at: https://www. elsevier.com/journals/the-journal-of-heart-and-lung-transplantation/1053-2498/ guide-for-authors. Accessed June 23, 2021.

36. Danovitch GM, Delmonico FL. China on the brink: there is hope for the end of their use of executed prisoner organs. Hepatobiliary Surg Nutr. 2015;4:136-7.
37. Wigmore SJ, Hunter JG. Editorial policy on clinical transplantation articles from the People's Republic of China. World J Surg. 2010;34 1742.

38. Caplan AL, Rockman HA, Turka LA. Editorial position on publishing articles on human organ transplantation. J Clin Invest. 2012;122:2.

39. Retraction Watch. Journals retract more than a dozen studies from China that may have used executed prisoners' organs. Available at: https://retractionwatch.com/ 2019/08/14/journals-retract-more-than-a-dozen-studies-from-china-that-mayhave-used-executed-prisoners-organs/. Accessed June 11, 2021.

40. Retraction Watch. Journals have retracted or flagged more than 40 papers from China that appear to have used organ transplants from executed prisoners. Available at: https://retractionwatch.com/2020/04/15/journals-have-retracted-orflagged-more-than-40-papers-from-china-that-appear-to-have-used-organ-transplants-from-executed-prisoners/. Accessed June 11, 2021. 